\title{
DEVELOPING OF INTERCULTURAL COMMUNICATIVE COMPETENCE THROUGH TEACHING ESP IN A MIXED-ABILITY GROUP OF INTERNATIONAL STUDENTS
}

\author{
РАЗВИТИЕ МЕЖКУЛЬТУРНОЙ КОММУНИКАТИВНОЙ \\ КОМПЕТЕНЦИИ В ПРОЦЕССЕ ПРЕПОДАВАНИЯ АНГЛИЙСКОГО ЯЗЫКА \\ ДЛЯ СПЕЦИАЛЬНЫХ ЦЕЛЕЙ В ГРУППЕ ИНОСТРАННЫХ СТУДЕНТОВ \\ С РАЗНЫМ УРОВНЕМ ПОДГОТОВКИ
}

\author{
L. V. Viktorko \\ Л. В. Викторко \\ Belarusian State University, ISEI BSU, Minsk, Republic of Belarus \\ victorka@tut.by \\ Белорусский государственный университет, МГЭИ им. А. Д. Сахарова БГУ, \\ 2. Минск, Республика Беларусь
}

\begin{abstract}
The article is devoted to the need to develop intercultural communicative competence in the field of foreign language teaching. For international students training to become professionals in any specific domain, cross-cultural awareness is at least as important as developing linguistic competence. The article expands upon certain methods and activities to be used in ESP classes, in order to develop intercultural communicative competence.

Статья посвящена проблеме развития межкультурной коммуникативной компетенции в процессе обучения иностранному языку. При овладении профессиональными компетенциями обучение иностранных студентов культурным различиям столь же важно, как и развитие их языковых компетенций. Автор рассматривает некоторые методы и приемы, рекомендуемые для развития межкультурной коммуникативной компетенции при обучении английскому языку для специальных целей.
\end{abstract}

Keywords: English for specific purposes, culture, cultural identity, intercultural communicative competence, sociocultural approach.

Ключевые слова: английский язык для специальных целей, культура, культурная идентичность, межкультурная коммуникативная компетенция, социокультурный подход.

https://doi.org/10.46646/SAKH-2020-1-136-139

Intercultural communicative competences today becomes an integral part of specialist's general professional competence as it expands the opportunities for access to the latest professional information in foreign languages, thus helps to improve professional knowledge and skills. That is why international students with different levels of language proficiency choose to obtain a higher education in the English language.

So, foreign language teachers in higher education institutions face rapidly changing circumstances and the pressure to quickly move from problems to solutions. Consequently, higher education institutions keep adjusting, changing and learning.

The study of English for specific purposes (ESP) is focused on learners' professional needs. International students who choose to study in English at different Belarusian universities should acquire a good command of it to understand professional texts and communicate effectively when fulfilling the tasks connected with their study, research or work situations.

Teaching foreign languages to non-linguist students is a demanding task. It is easy for students to get frustrated in a class of mixed ability. Stronger students may feel held back, weaker students may feel pressured. The teacher may feel stressed. The situation is becoming increasingly complicated when we teach a language for specific purposes, especially when we deal with a mixed-ability group of international students. Heterogeneity makes the teaching-learning process a challenge for the teacher. This involves a number of decisions regarding such fundamental aspects as what to teach (materials, topics, etc.), how to teach (lesson planning, preparation, management, pair and group work interaction, feedback, etc.) and to whom (for example, should all students be taught the same and use similar materials if their levels are quite different?) [1, p. 9].

ESP for international students can be introduced by means of learning modules such as the Intercultural Communication module, the Professional Communication module.

Learning module tools seem to be efficient for teaching students as the guiding principles of modular training include modularity, structuring - splitting educational content into separate elements, dynamism, efficiency, flexibility, perceived perspective, variety of methodological counseling, parity [2, p. 19].

A module is presented by:

- its own content as a logically complete unit in the structure of a training course; 
- its own learning objectives in accordance with the content;

- technological and methodological 'equipment' that ensures the didactic process to be in line with the learning objectives;

- forms of training organization required for the didactic process;

- control system of the training and evaluation/ assessment outcomes [3, p. 15].

The training outcomes depend not only on a teacher, but also on a student as a direct participant of the learning process. So the student's tasks are as follows:

- development of cognitive abilities and research skills;

- formation of independent thinking;

- self-development and self-realization.

Advantages of using modular technologies are obvious:

- consistency of the internal components of the course;

- flexibility of the course structuring;

- solution to the problem of integration, differentiation, and deepening of the course complexity;

- the possibility of training in any locality and at any time;

- full immersion in the continuous educational process not only with the help of teaching aids, but also computer learning resources: audio lectures, training programs, slide presentations, etc.;

- improvement in the level and quality of knowledge;

- formation of the integral scope of theoretical knowledge;

- well ordered, step by step memorization;

- independent search for information, its creative interpretation.

However, there are some disadvantages, including the following:

- lack of developed self-control skills in most students;

- students differ in age, which implies different approaches to teaching;

- different levels of students' willingness for independent processing of theoretical and practical material.

Usually students are not grouped according to their levels. Obviously, this leads to some difficulties. The lessons are circumstanced by students' level variety so teachers have to make complex decisions to adjust their teaching to students' levels and each individual student's needs.

The solution to many of the problems seems to be in (1) trying to vary topics and content so that students are more likely to feel interested, (2) setting open-ended tasks so that learners may complete them according to their own levels, (3) providing activities with varying degrees of difficulty so that sometimes even more advanced students find them a challenge (which will also help to increase their motivation) or even giving them more difficult tasks, (4) using pair and group work for one to help another, (5) grouping them according to their levels, (6) attending to particular individual difficulties (and advanced students), (7) providing additional material to those who may need it, etc. [1, p. 7].

As regards speaking activities most of the students in the mixed-ability group are first reluctant to talk, especially when they realize that more advanced students can speak fluently. Speaking tasks are used as a complement to another task, for example, a reading comprehension task, which is used as a motivator. Thus, students work either in pairs or groups, and they are grouped together depending on their levels, so that no one may feel ashamed of his/ her performance. If there is a need to identify a group leader, an advanced learner may work with the lower level students so that s/he may help the others.

Dealing with a multicultural group of international students in the English language classroom, the teacher should always be aware of their social and cultural backgrounds. Since humans are fundamentally social beings, individuals cannot live without cultures of their own. J. Bruner notes that "culture shapes mind...it provides us with the tool kit by which we construct not only our worlds but our very conceptions of ourselves and our powers." He further states that "you cannot understand mental activity unless you take into account the cultural setting and its resources, the very things that give mind its shape and scope. Learning, remembering, talking, imaging: all of them are made possible by participating in a culture" [4, p. x-xi]. Whether human culture is a shared system, in essence, it serves as a context within which we communicate.

It's no doubt that international students are always eager to speak about their own country, culture, language, traditions, holidays, music, etc. Identity is an important feature of a person's psyche, since it defines one's relationship to other humans. Learning English as a second or foreign language is not simply a matter of code switching. It cannot be separated from the awareness of differences between the home and target culture. The issue of knowledge of the country, the place where a person was born and grew up, is relevant due to many circumstances. The place that is especially significant for a student (city, village where he was born) is the object of particular importance. In this very place his personal identity was shaped, as the life here is connected with his family and friends.

Intercultural awareness includes an awareness of regional and social diversity in both worlds. It is also enriched by awareness of a wider range of cultures than those carried by the learner's native and target language.

One of the current tasks that teachers and university professors face today is the necessity of bringing up a multicultural personality with a strong socio-cultural outlook. It is important to pay students' attention to similarities and differences in the perception of reality by different ethnic groups.

We believe that a foreign language course for university students should include instructional modules that allow students to study different cultures. As during the school course due to immaturity of students and their little life experience 
intercultural competence can be acquired rather than developed. Many scholars have emphasized the importance of the development of intercultural communicative competence in the study of foreign languages since it involves the ability to perceive facts about different cultures with tolerance, a desire to see the behavior of its native speakers with their own eyes.

Language is a medium of communication that expresses, embodies, and symbolizes cultural reality. So, language and culture are closely related and interactive. The sociocultural approach which now dominates the educational environment as a whole and the English language classroom in particular has among its strategic values the formation of cultural and intercultural awareness. The sociocultural approach makes it possible to make the learners aware of the differences between themselves and people from other countries or other backgrounds, especially differences in attitudes and values.

But what adds to the complexity of the issue is the fact that our culture is so pervasive that we don't ever think about the effects it has on our way of life, our thoughts, our actions, etc. as the proverb has it: "The last thing a fish would ever notice would be water". So, when educators decide to develop intercultural competence, the learning process still calls for the learner's cultural awareness and self-analysis.

Teaching foreign languages in the context of dialogue of cultures requires from educators to take serious steps towards the analysis of culture-related materials which can be used to simulate the cultural space in the classroom environment, with the student being constantly and continuously introduced to these cultures. As no textbook perfectly integrates language and culture education, teachers need to build up supplemental activities to make culture learning a consistent component of their language classes. Thus, the introduction of the cultural content into language education involves decisions related to the selection of topics, themes and perspectives.

It should be mentioned that efficient teaching can only take place when - alongside with listening and reading texts on cultural issues - varied culture oriented activities and interactive tasks are introduced, such as:

- discussions or debates based on a set of questions related to cultural and cross-cultural issues,

- brainstorming tasks consisting in the pooling of ideas or solutions to a given problem,

- role-plays based on role-cards presenting conflicting opinions,

- mind mapping,

- compare and contrast tasks calling for a comparative analysis of a given aspect of life in two cultures,

- webquests,

- projects based on internet exchanges, where students are encouraged to reflect on their own culture and to justify their opinions.

Most of the above activities base on the analysis of differences and reflection on one's own culture and identity. In addition to practical classes aimed at bridging the gap between cultures an effective tool is the use of gaming activity which, in addition to controlling functions, is also used for cognition and motivation.

As regards to students' reading and writing skills, lower level students seem to be more confident in themselves. Though they are quite reluctant to participate in the reading tasks at the beginning, later they stop perceiving the group heterogeneity as all the students are given texts with specialized vocabulary. Their level of comprehension does not differ greatly since more advanced students have a good command of general English only. This fact is quite motivating for all of them because the more advanced students make great efforts to maintain their "status" of being the best in the class, whereas lower-level learners are happy to know that the others do not recognize the vocabulary [1, p. 12-14].

Vocabulary learning and teaching is very important in learning ESP. In order to develop students' communicative competence, language teachers should encourage them to learn as many words as possible. There are different opinions about teaching ESP courses but vocabulary is crucial in this sphere of teaching. Vocabulary is an integral part of ESP and it is very important for learners to build a consistent body of terms that are specific to and occur frequently in their area of study. It is the basis they will require for their future careers. That is why it is important to teach vocabulary in such a way as to help learners make sense of future problems and encourage continuous learning.

Vocabulary acquisition is usually perceived as a boring activity by the learners. The teacher's main goal is to improve this situation and turn the learning of ESP vocabulary into a pleasant experience.

Given that international students do not normally do homework or revise their lessons at home (unless under pressure - a test), maximum exposure must happen in class. It is difficult to learn ESP words because they are not encountered very often. Thus, in a desire to expose the students to a large amount of vocabulary and because the classes have limited time the teacher should give the students more practice time and chances to encounter the same terms more often. This can be achieved by including more activities that contain the specialized vocabulary and more revision-type exercises.

Teaching material is normally divided into certain topics, specific to the students' field, to go through over a semester. For example, in the case of Ecology students, such topics would be: Air Pollution, Water Pollution, Soil Pollution, Fossil Fuels, Renewable Energy, Endangered Species and others. Each topic has a specific terminology and there are also specialized words that pervade all these topics. Thus, the activities practicing them will also be focused more on usage and possible combinations (collocations).

The practice activities for revision, consolidation and reinforcement are the ones that make the difference, as the learners see, hear and are required to use the terminology in various contexts. Most standard exercises often employed are: word maps, hangman, puzzles, crosswords, matching games (match with definition, match with an image, match with the characteristics), multiple choice, fill in gaps, cloze exercises, identifying terms in texts and many other types of vocabulary activities [5].

To sum up, it must be concluded that the linguistic, the communicative and the intercultural competences should go hand in hand in teaching both General English and English for Specific Purposes. Good command of English, as well 
as fluency, are acquired by vocabulary building, which, in turn, is accomplished by exposing the learners to a carefully selected corpus of authentic materials and to real-life situations where context-appropriate language is used.

\title{
REFERENCES
}

1. Languages for Specific Purposes: Searching for Common Solutions / ed.: D. Gálová. - Newcastle : Cambridge Scholars Publishing, 2007. - 245 p.

2. Конылева, A. В. Модульное обучение как средство управления самостоятельной работой студентов / А. В. Конышева // Высшее образование в России. - 2009. - №11. - С.18-25.

3. Учебно-методический комплекс: модульная технология разработки : учеб.-метод. пособие / А. В. Макаров [и др.] ; под ред. А.В. Макарова. - Минск : РИВШ БГУ, 2001. = 118 с.

4. Bruner, J. The culture of education / J. Bruner. - Cambridge ; Massachusetts : Harvard Univ. Press, $1996 .-240$ p.

5. Stoica, A. Developing communicative and intercultural competence in teaching English for Specific Purposes [Electronic resource] / A. Stoica // Researchgate. - Mode of access: https://www.researchgate.net/publication/47807326_ DEVELOPING_COMMUNICATIVE_AND_INTERCULTURAL_COMPETENCE_IN_TEACHING_ENGLISH_ FOR_SPECIFIC_PURPOSES. - Date of access: 07.03.2020.

\section{ИЗУЧЕНИЕ БУДУЩИМИ СПЕЦИАЛИСТАМИ УЧЕБНОЙ ДИСЦИПЛИНЫ «ТУРИСТСКО-РЕКРЕАЦИОННАЯ ДЕЯТЕЛЬНОСТЬ» КАК УСЛОВИЕ УСТОЙЧИВОГО РАЗВИТИЯ ОБЩЕСТВА STUDY BY FUTURE SPECIALISTS OF THE DISCIPLINE «TOURIST-RECREATIONAL
ACTIVITY» AS CONDITION OF SUSTAINABLE SOCIETY DEVELOPMENT}

\author{
Врублевская В. И., Борисевич А. P. \\ Vrublevskaya V., Borisevich A.
БГПУ им.М.Танка, г.Минск, Республика Беларусь bor_angela@mail.ru
vrvictoriya@yandex.ru \\ BSPU M.Tanka, s.Minsk, Respublika Belarus
}

\begin{abstract}
Современное состояние системы высшего образования способствует развитию и включению в учебные планы различных специальностей учебных дисциплин, позволяющих формировать у будущих специалистов компетенций нового уровня. Данные профессионально-личностные качества и характеристики студенческой молодежи, применяя их в будущей профессиональной деятельности, будут направлять жизнеспособность общества в русло устойчивого развития.

The modern state of the system of higher education assists development and plugging in the curricula of different specialities of the disciplines allowing to form for the future specialists of competenses of a new level. These professionally-personality qualities and descriptions of student youth, applying them in future professional activity, will direct viability of society in the river-bed of steady development.
\end{abstract}

Ключевые слова: будущие специалисты, физическая культура, туристско-рекреационная деятельность, компетенции, устойчивое развитие общества.

Keywords: future specialists, physical culture, tourist-recreational activity, competenses, sustainable society development.

https://doi.org/10.46646/SAKH-2020-1-139-142

Устойчивое развитие общества характеризуется необходимым достижением целей, заявленных Организацией Объединенных Наций. ООН призывает к действию: надо стремиться сделать планету лучше, защищать окружающую среду.

Вступив в XXI век, человечество столкнулось с целым рядом сложных проблем, обусловленных, с одной стороны, противоречиями между обществом и природой, с другой стороны, политическими, экономическими, культурными противоречиями между экономически развитыми и остальными странами мира. Трансформационные процессы в мире связаны, прежде всего, с глобализацией - объективным процессом превращения экономик отдельных стран из относительно замкнутых систем в элементы единого мирового хозяйства. В основе глобализации лежит международное разделение труда и связанные с ним экономические, политические и другие отношения между государствами, предприятиями, фирмами, объединяющие национальные экономики, создающие единый мировой рынок и его инфраструктуру. 